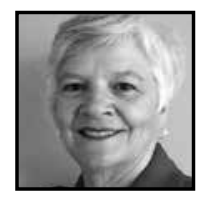

\title{
Creating an Early Childhood Nature-Based Play Space-A Success Story
}

\author{
Elizabeth Munroe, St. Francis Xavier University
}

\section{ABSTRACT}

This article chronicles the successful expansion of an existing play space, filled with commercial play equipment, to include a nature-based area for the young children attending an early childhood program in a Canadian First Nations community. This change was sparked by the centre director's participation in a one-hour workshop focused on the importance of children being in nature. The subsequent process the director went through to provide a nature-based space is described here. The responses of the children and the early childhood educators to the new space are reported. Concluding thoughts about why this particular director might have been inspired and able to effect this change are offered.

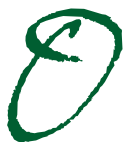

n Earth Day in April of 2013, the David Suzuki Foundation issued a challenge for people to spend 30 minutes in nature for 30 consecutive days. In a short video explaining the initiative, Suzuki noted, "Scientists have shown that when we connect with nature, we're smarter, healthier, even more generous" (David Suzuki Foundation, n.d.). In addition to contributing to individual mental and physical health, a close connection to nature leads to a passionate regard for nature, and thus is promising for the future of our planet because, as Suzuki explained, "you only fight and work hard to protect what you love" (Canadian Broadcasting Corporation, 2013).

These recent reminders of the importance of being in nature build upon more than a decade of research, in Canada and around the world, supporting the importance of adults and children spending time in nature (Louv, 2005, 2011). The research has sparked a sophisticated worldwide movement to increase children's experiences with 
nature (childnature.ca; childrenandnature.org; Keeler, 2008). Even with all the research and resources available to support children spending increased time in nature, challenges related to changing educators' beliefs and practices and modifying outdoor play spaces can be significant. In a recent study, early childhood educators were asked to describe the barriers that prevented them from taking the children in their care outdoors for greater periods of time (Munroe \& McLellan-Mansell, 2013). Almost all the educators expressed concerns about safety. Inadequate, poorly maintained, or impoverished, uninteresting outdoor play spaces with no provisions for the adults' comfort were listed as impediments to their taking the children outdoors.

Despite the complexity of transforming educators' beliefs and practices (Guskey, 2002), a promising story of change can occasionally be told. This article chronicles the successful expansion of an existing play space, originally filled only with commercial play equipment, to include a nature-based area for the young children attending an early childhood program in a Canadian First Nations community. This change was sparked by the childcare director's participation in a one-hour workshop during which she viewed images of nature-based play areas and listened to a review of the researched benefits of playing in nature. The process the director went through, from designing the nature-based space, to obtaining funding and deciding on materials for the space, is described here and the responses of the children and the early childhood educators to the new space are reported.

Following the description of the successful change to the outdoor space at this one centre, the author proposes some thoughts as to why this particular director might have been inspired and able to effect change for the benefit of the children in her program. Of the 30 workshop participants, representing eight First Nations communities in the province, only this one director was spurred into action to modify the outdoor space at her centre. This might suggest the workshop was a failure. In contrast, the fact that the workshop inspired one participant to make such dramatic change can be seen as a surprising, wonderful result. Single-event professional development sessions have long been acknowledged as ineffective in terms of causing changes in educators' practice (Sparks \& Hirsch, 1997). Knowing this, there was little expectation that the workshop would do more than heighten awareness of the importance of playing in nature and spark interest in different kinds of outdoor play spaces. The action-oriented response of this one director is considered in relation to the concepts of horizontal and vertical transfer (Joyce \& Calhoun, 2010), the zone of proximal development (Vygotsky, 1978), and brain research, emotion, and learning (Wolfe, 2006). 
This paper invites readers to celebrate a successful story of change. The review of the importance of children playing in nature and the description of the transformation of an outdoor play space may inspire others to bring elements of nature into their centre's outdoor areas. The concluding thoughts about why one woman might have been inspired to take action after attending a workshop may encourage those who design professional learning opportunities to modify some elements as they offer single-event sessions.

\section{Playing in Nature-Based Spaces Rather Than Commercial Playgrounds}

Researchers have found that children prefer to play in nature-based spaces rather than on commercial playground equipment. As one kindergarten-aged boy explained, "Climbing rocks is more fun than climbing trees-but climbing trees is more fun than the boring playground equipment" (Fjørtoft \& Sageie, 2000, p. 84). Studying four- to sixyear-old children's preferences for play in their schoolyard, Azlina and Zulkiflee (2012) found that the children "seemed to prefer the more natural play area that consisted of trees, a log, benches, sand and turf" (p. 282). They noted that children could have chosen to climb and slide on the playground equipment, but instead they chose to climb on the logs and benches in the more natural space. Perhaps some of the enjoyment of playing in nature derives from children's increased freedom to explore without the interference of adults (Handler \& Epstein, 2010; Kernan, 2010; Little \& Eager, 2010).

In addition to having fun, children have the opportunity to develop physically and socially and to enhance their reasoning and observation skills when they play outdoors (Handler \& Epstein, 2010; White, n.d.). Fjørtoft (2004) conducted a nine-month-long study wherein one group of five- to seven-year-old children played in a natural environment (a forested area with shrubs, trees, rocks, and grassy spaces), and a comparable group of similarly aged children played on more traditional playground equipment (sandpit, swings, seesaw, slides, and a climbing frame). The researcher concluded, "When provided with a natural landscape in which to play, children showed a statistically significant increase in motor fitness" (p. 21). In particular, the children who had played in the natural setting had increased balance and co-ordination. Fjørtoft attributed this positive development in motor skills to the "complex [natural] physical environment, where the landscape structures provided diverse functions for play" (p. 38). 
Fjørtoft (2004) also commented that "more demanding tasks" had been learned by the children who had played in the natural environment, perhaps due to the complexity afforded by the natural space. Many other authors have commented on the degree of challenge that play in nature offers, and they have suggested that the complexity of the natural environment leads children to self-monitor in terms of risk (Almon, 2009; Copeland, Sherman, Kendeigh, Kalkwarf, \& Saelens, 2012; Handler \& Epstein, 2010; Miller, 2007). Traditional play equipment often offers little to no challenge or risk because of increasingly stringent safety regulations for outdoor play areas. Surprisingly, such lowrisk environments can actually result in children playing in dangerous ways as they seek to challenge themselves (Almon, 2009; Copeland et al., 2012; Dwyer, Higgs, Hardy, \& Baur, 2008; Kernan, 2010; Stephenson, 2003). Gill (2005) quoted Helle Nebelong, a Danish landscape architect as saying,

I am convinced that standardized play-equipment is dangerous. When the distance between all the rungs on the climbing net or the ladder is exactly the same, the child has no need to concentrate on where he puts his feet. This lesson cannot be carried over into all the asymmetrical forms with which one is confronted throughout life. (para. 4)

If willingness to take a risk is "fundamental to human learning as we endeavor to develop new skills, try new behaviors, develop new technology, and abandon the familiar to explore what we know less well" (Little \& Eager, 2010, p. 499), perhaps we need to reconsider the effects of low-risk commercial play structures on children's development.

Children who spend time in nature are more likely to develop an environmental ethic (Louv, 2005). "The health of the earth is at stake.... How the young respond to nature, and how they raise their own children, will shape the configurations and conditions of our cities, homes-our daily lives" (Louv, 2005, p. 3). Danks (2010) offered a compelling explanation as to how nature-based spaces lead to children's development of an environmental ethic. A paved play space filled with plastic and metal structures makes the natural systems of the world invisible to children, whereas:

ecological schoolyards provide opportunities for students to build awareness about local ecology and their own neighborhoods. They help children notice the birds in the city, the butterflies that visit their flower gardens, the patterns falling rain makes on the soil. Green schoolyards help students mark seasonal changes with the turning of leaves in the fall, the migrations of wildlife, and the length of shadows on the ground, and in so doing, make them better readers of their surroundings. (p. 5) 
Ultimately, children who spend time in nature rather than in paved play spaces with commercial playground equipment "make connections between themselves and local natural systems... [and] learn that they have an impact on their environment and have opportunities to heal it" (Danks, 2010, p. 5). As the well-respected environmentalist Wallace Stegner wrote, "Whatever landscape a child is exposed to early on, that will be the sort of gauze through which he or she will see all the world afterwards" (cited in Danks, 2010, p. 12). Seeking to add to more than a decade of evidence confirming a correspondence between early experiences in nature and adult's environmental ethic, Vadala, Bixler, and James (2007) conducted lengthy interviews with 51 people between the ages of 18 and 35. "The individuals nominated were highly motivated and exceptional field naturalists, environmental educators, or conservationists" (p. 5). Ten non-outdoor enthusiasts made up the contrast or control group for this study. The researchers found that recreational and environmental preferences are determined in childhood, although they cautioned that the complexities surrounding this kind of research are many.

For First Nations people, spending time in nature and on the land has strong cultural implications. The Assembly of First Nations (n.d.) described the special relationship Aboriginal people have with the earth and all living things in it as a "profound spiritual connection to Mother Earth" (para 2). Participants in Greenwood and Shawana's study (2003) emphasized that including the natural environment in childcare settings would promote "holistic learning, a reflection of who we are" (p. 58). One might assume that in communities where the educators, children, parents, and grandparents are First Nations people, there would be fewer barriers to children spending time in nature-based settings; that this would be a high priority because of strong cultural connections to the land. However, there is considerable complexity inherent in education for Aboriginal children because of the need to intertwine the goals of mainstream academic success alongside "the essential establishment of children's identity valuing and giving expression to Aboriginal cultures" (Stairs \& Bernhard, 2002, p. 309). Greenwood (2009) noted "one of the greatest challenges facing early childhood caregivers is to take principles of Indigenous knowledge and actualize them in current practice" (p. 75). The First Nations educators who collaborated with Munroe and McLellan-Mansell (2013) felt responsible for preparing the children for school, and they perceived that taking the children outdoors detracted from that goal. On the other hand, they expressed a longing for children to spend more time playing in nature, and they bemoaned the prevalence of "screen time" (Tandon, Zhou, Lozano, \& Christakis, 2011) replacing outdoor time when children are at home. 
There are many benefits that may arise from children spending time in nature-based play areas rather than playgrounds full of commercial equipment. As individuals, children develop physical, social, and emotional skills when they play in nature. It appears they also develop a sense of stewardship towards nature. Considering that children are our society's future leaders, the development of an environmental ethic is crucial. Vadala et al. (2007) emphasized the importance of adults providing opportunities for children to be in nature. The story that follows celebrates one early-years-program director's efforts to accomplish that goal.

The details offered in this story derive from a three-year research study in partnership with the Mi'kmaw Kina'matnewey (MK) First Nation Student Success Program (FNSSP) in Nova Scotia, focused on enhancing the experiences for children in early childhood settings. During conversations with the participants referred to in this article, the author took notes and scribed some direct quotes. The particular director whose story is described here read the final version of this paper and confirmed that the events surrounding this change to her centre's outdoor play space were accurately depicted.

\section{Inspired by Images and Information}

As part of the collaborative research with MK FNSSP, the author designed and led professional learning opportunities for the educators who worked in various early childhood programs in First Nations communities in Nova Scotia. The primary purpose of these workshops was to facilitate collaboration and networking amongst the educators on the topics of language and cultural enrichment. Prior to the first workshop, the author and the FNSSP coordinator visited many communities to see their early childhood programs and speak with the educators. During these conversations, some of the educators expressed frustration with their outdoor play spaces, and they asked questions about designing new outdoor areas. Although none of the educators ( $97 \%$ of whom were First Nations people) specifically linked their interest in improving outdoor play with the Aboriginal context in which they worked, devoting part of the first workshop to the topic of taking children outdoors was seen as complementary to the overall focus on the cultural enrichment of the programs.

Thirty early childhood educators and directors from eight First Nations communities in Nova Scotia attended the first all-day workshop. One hour of the workshop was focused on the importance of children being outdoors in nature. The author shared photos and information from a recent trip to Sweden, where she had visited 
childcare centres with extensive and interesting outdoor spaces. The play spaces had some paved sidewalks for the young children to ride tricycles, but there were also a lot of shrubs, trees, grass, rocks, sand pits, small gardens, and an interesting slide built into the hill (Figures 1-3). Participants viewed a brief video describing several Swedish early childhood educators' inquiry into children's use of outdoor space (OMEP, 2010). Finally, the workshop participants viewed and discussed the DVD, Leave No Child Inside (Harvest Resources, 2006), which included inspiring photos of naturalistic outdoor play spaces for young children as well as research-based information on the benefits of outdoor play.

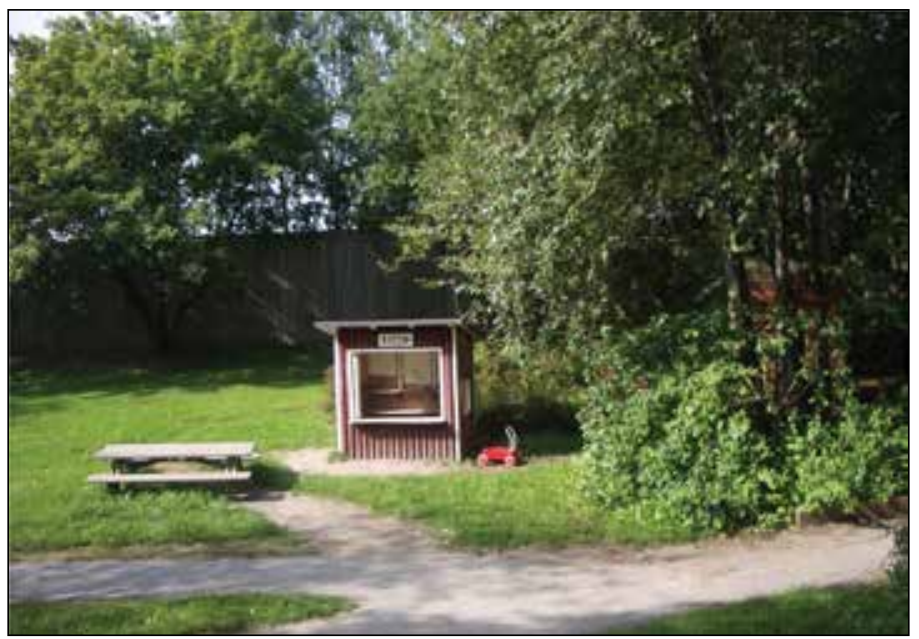

Fig. 1: Paved and grassy areas (Swedish child care centre)

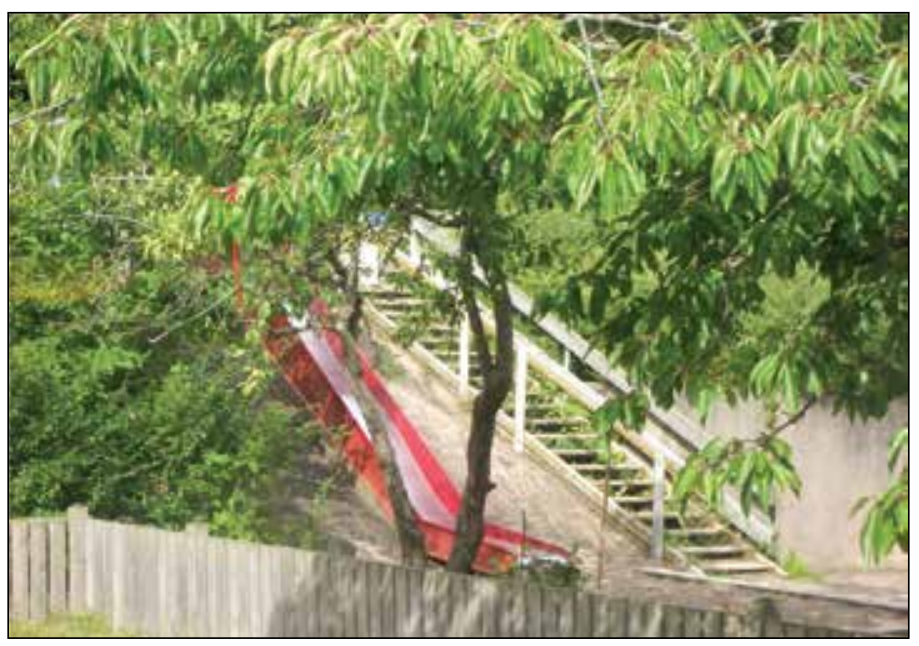

Fig. 2: Slide and stairs built into the hill (Swedish child care centre) 


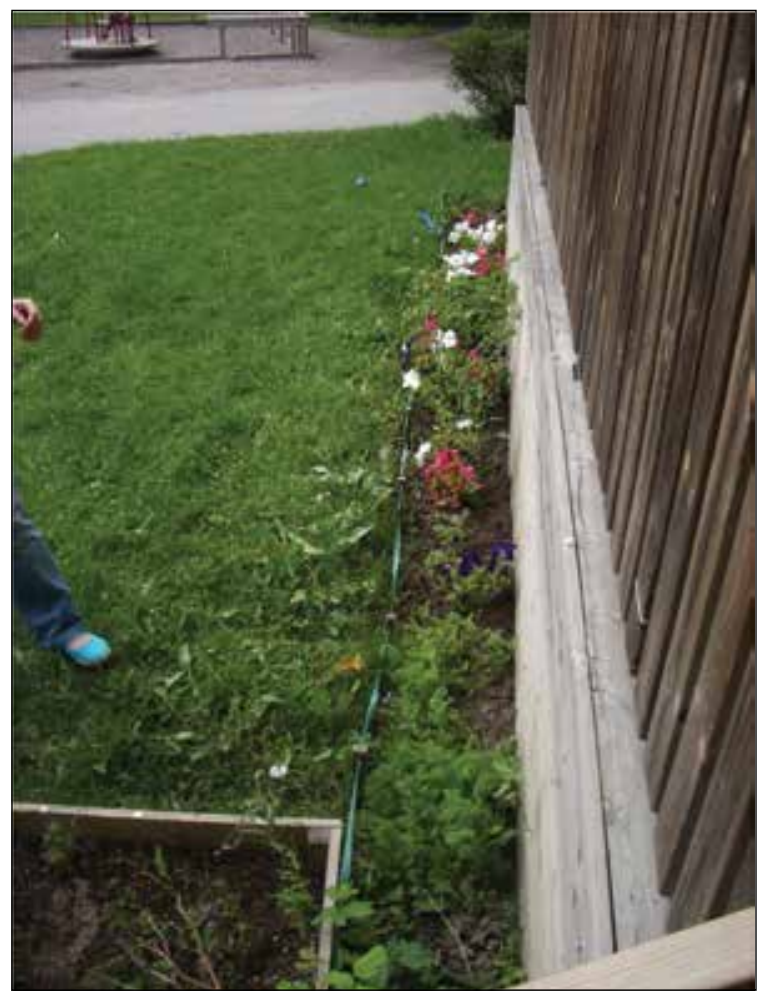

Fig. 3: Flower and vegetable garden (Swedish child care centre)

Unbeknownst to the author, that hour of viewing images and discussing naturebased play spaces had a transformational effect on the director of one community's early childhood program. The workshop was held towards the end of October. By midNovember the director, Suzette, ${ }^{1}$ contacted the author, asking to borrow the Leave No Child Inside CD (Harvest Resources, 2006). She indicated that she was applying for a grant to build a nature-based extension to their existing play area, and she wanted to include some of the information from the CD to strengthen her application. Towards the end of November, the FNSSP coordinator and the author visited the director at her centre and learned more about her plans.

Suzette confirmed that she was inspired by the images and information offered in the workshop. She exclaimed with regret that she had applied for and received funds for new playground equipment two years previous but had chosen a play structure from a glossy commercial catalogue (Figure 4). She had not known about naturebased materials and equipment for outdoor play spaces. White (2004) proposed, 
"When most adults were children, playgrounds were asphalt areas with manufactured, fixed playground equipment such as swings, jungle gyms and slides, where they went for recess. Therefore, most adults see this as the appropriate model for a playground" (p. 1). This seemed to be partially the case for Suzette. Her previous decisions about playground equipment were to purchase commercial structures. But, she reported that her own fondest childhood memories were of messing around outside in natural spaces. The images shown during the workshop brought those memories back to her and introduced her to ways to incorporate elements of nature in outdoor play spaces for young children.

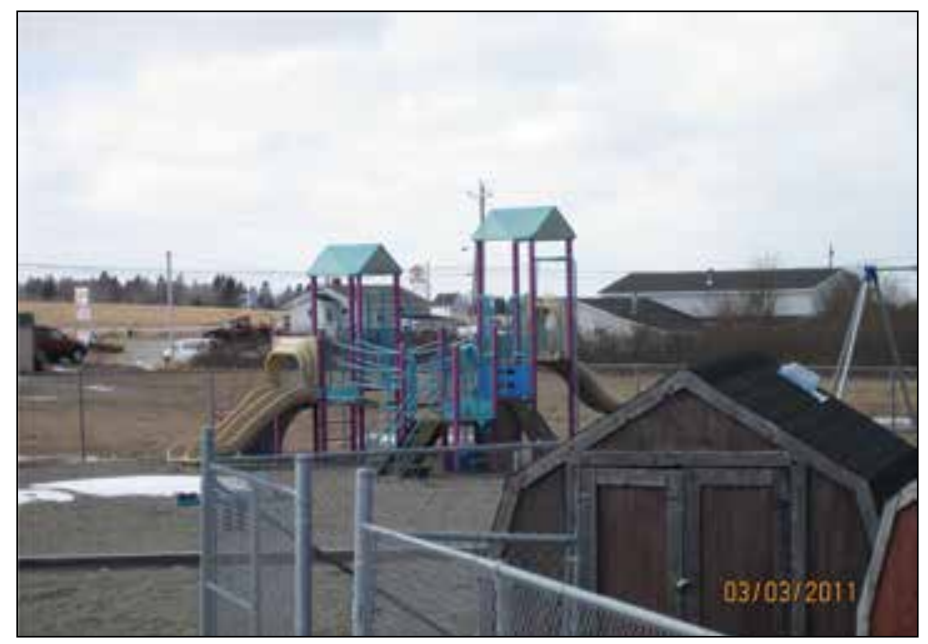

Fig. 4: Commercial play structure on gravel surface (Suzette's centre)

During the November visit, Suzette showed the author a plan she had created for a nature-based play extension to her centre's current outdoor play area (Figure 5). She had planned several pathways with concrete blocks, logs and tires, a hill and tunnel, a place to plant flowers, a place to dig in sand, a gazebo with a table and stools for children and adults to be protected from the hot sun or the rain, storage bins, and other benches, all situated in an area with grass, shrubs, and trees. Although there is a forest very near to Suzette's centre, supervision of the children in the forest poses some challenges and the ground is very wet. Suzettte wanted a fenced play area with natural elements, for children to have daily easy access without the necessity of written parent permission to take the children off site. 


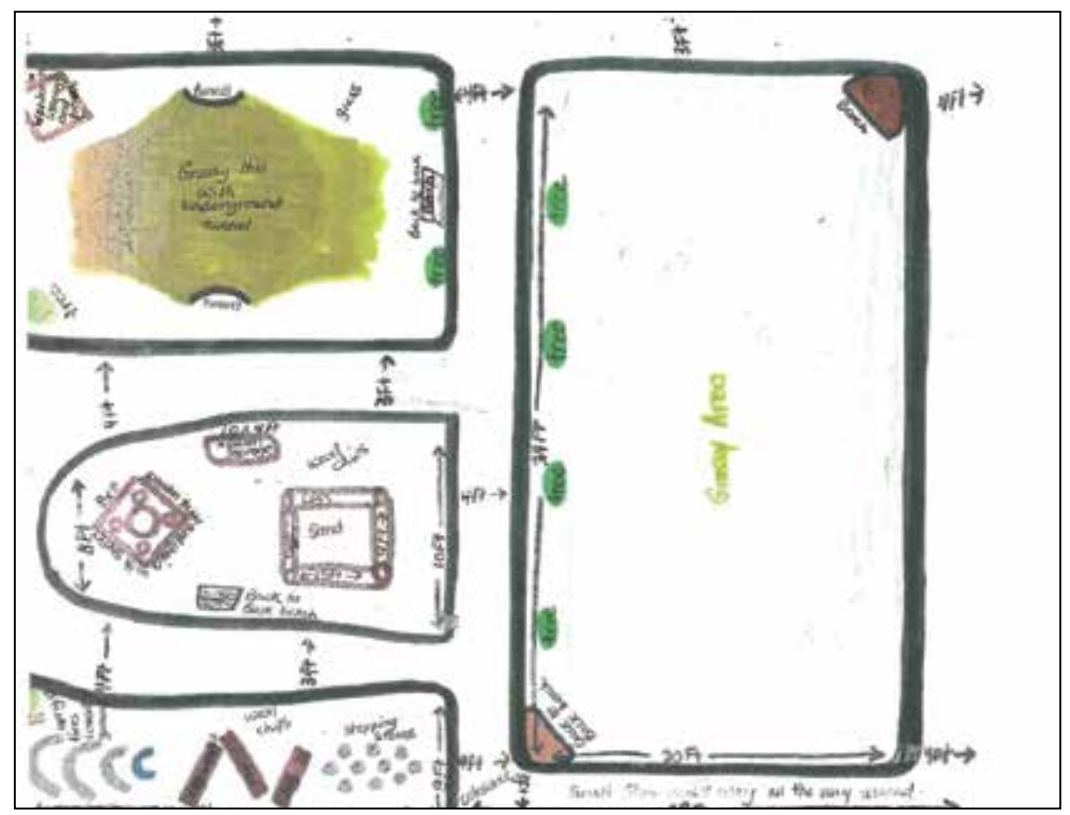

Fig. 5: Suzette's plan for a nature-based play space for her centre

As with many initiatives, the process of turning a dream into a reality may be slowed by unforeseen events. This was the case for the creation of Suzette's nature-based play area. While Suzette was negotiating with the potential granting agency for funds to build the new play space, she gained the impression that their representative was quite unfamiliar with nature-based play spaces. Indeed, the representative suggested Suzette hire a specialist to design a safe and appropriate space. Suzette declined to do that because of the expense, so the existing health and safety regulations were applied to her original plan. Suzette needed to make some changes to her plan, such as adding railings to reduce the danger of children falling off the top of the culvert that created the small hill in the space. She also had to ensure there would be no equipment that might hold standing water, so holes needed to be drilled in the tires that were to be embedded on their sides in the space. By March, the design for the nature-based play space had been approved, and the funds were awarded. The construction began in May, but progress was slow because the workers were also busy with several other building projects in the community, so when the young children finished their program in the middle of June, the play space was landscaped, but none of the play features were completed. After eight months, from the workshop in October to the middle of June, Suzette's dream had not yet become a reality, but it was close. Unfortunately, at that time, another professional opportunity arose that Suzette was very interested in 
and for which she was well qualified, so she ended her tenure as director. She was sad to leave, but pleased that there would be a new, nature-based play space ready for the children when they returned to the program in the fall.

\section{Early Responses to the Nature-Based Play Space}

The author visited the community early in October, almost exactly a year after the workshop, to see the new play area (Figures 6-9) and to hear from the educators how the space was being used. When asked what she thought of the new space, one educator commented, "It's nice to look at, pleasing on the eye. It's an extra place to play. It's nice to have grass instead of rocks." Another educator added, "I like the gazebo and chairs; the children can sit in the shade. It would be nice to have a tea party out there." The educators described the new space as "peaceful and relaxing" and mentioned that the benches for the adults to sit were a welcome addition.

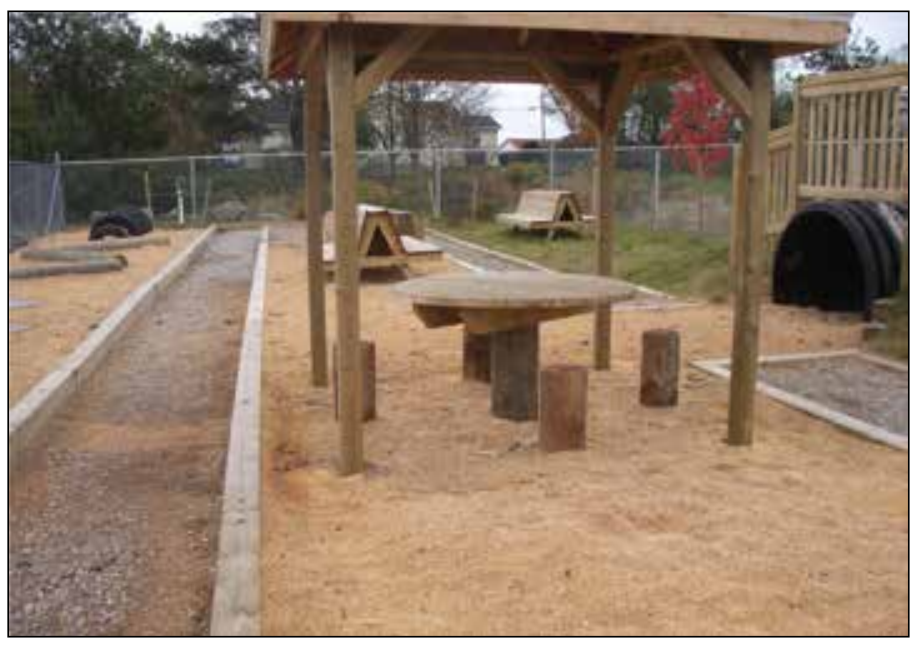

Fig. 6: New nature-based play space: covered gazebo for children and adults (Suzette's centre) 


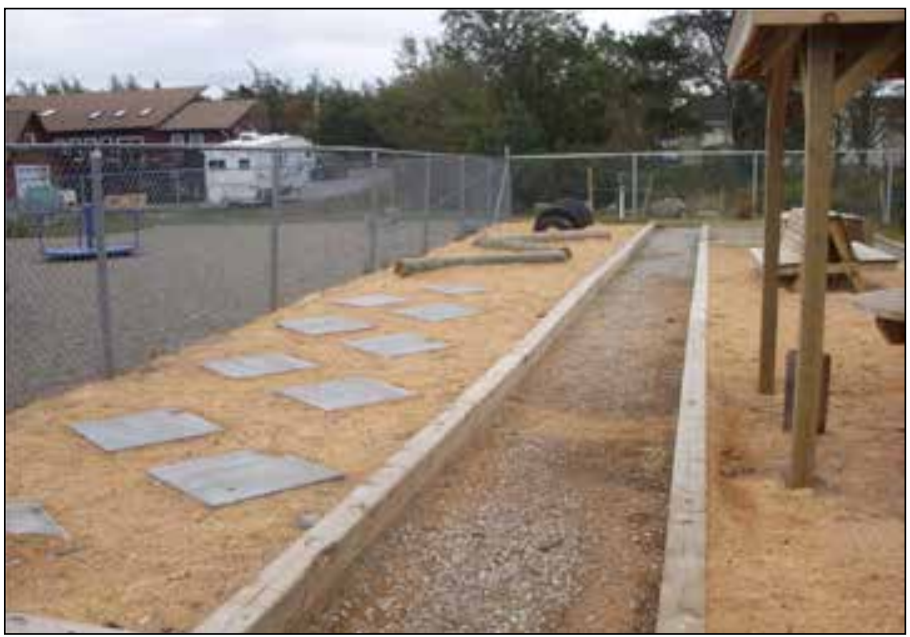

Fig. 7: New nature-based play space: interesting pathway, stepping stones, logs, and tires (Suzette's centre)

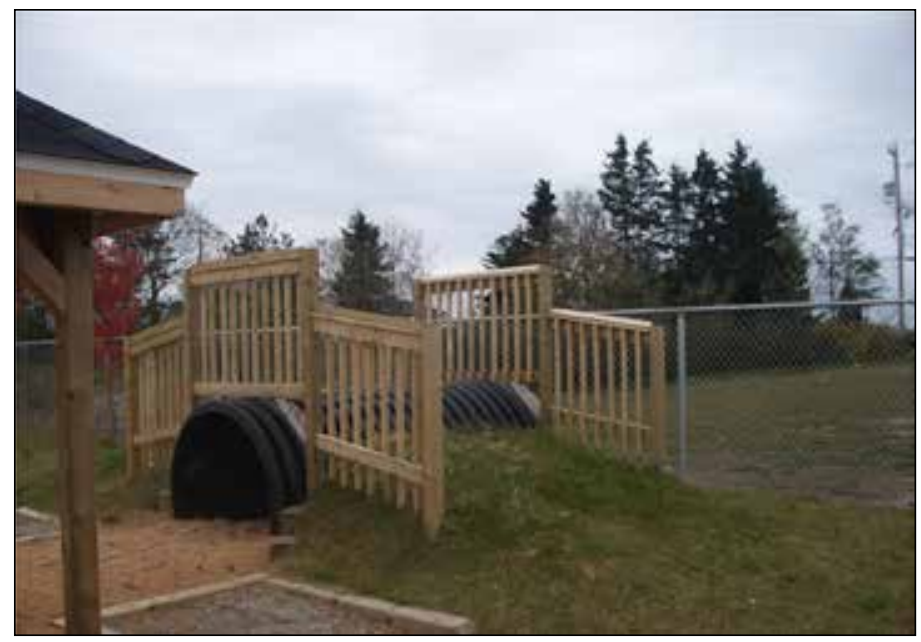

Fig. 8: Nature-based play space, tunnel, and bridge (with railings) at Suzette's centre 


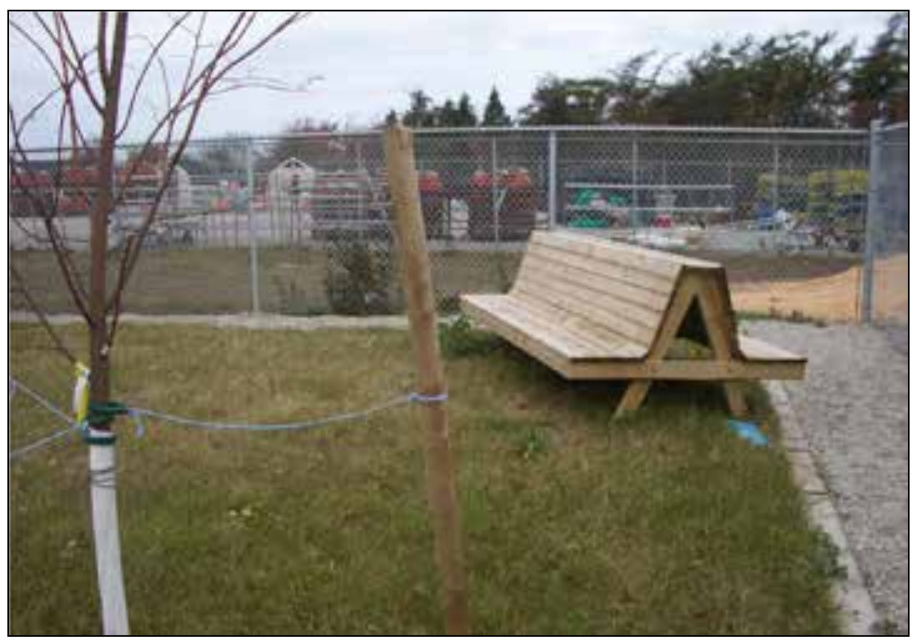

Fig. 9: Nature-based play space, with new grass and trees, and bench for the adults (or children) to sit (Suzette's centre)

The timing of the author's visit to the centre did not allow for any direct observation of the children playing outdoors, but the educators described the children's behaviour in the nature-based space as follows. "The children find things to do in there on their own. They roll down the hill, they make their own obstacle course on the steppingstones, logs, and tires, and they like the tunnel. They play hide and seek-there are more places to hide in that space." Although the trees were small, the children were able to find leaves in the new play area for some fall crafts. The educators commented they had not been able to do that before.

Many of the educators' observations about the children's play in the nature-based space echo the findings of Fjortøft and Sageie (2000) and Azlina and Zulkiflee (2012), as described earlier in this paper. The children were engaged in different kinds of complex activities in the new space. When the educators commented that the children were able to amuse themselves and the adults could relax and sit on a bench some of the time, it seems as if they were confirming Mauffette's (1998) claim that "making the outdoors more enjoyable for everyone is of utmost importance" (p. 21) and may lead to increased time spent in that environment. In this particular case, however, the educators indicated the new play area had not resulted in their taking the children outdoors for any longer periods of time. They were still concerned with spending adequate time indoors, supporting the children's learning in areas more directly related to school success. 
When asked if there were any challenges associated with the new play area, the educators admitted that the substitution of sawdust rather than wood chips was a problem because of allergies experienced by one educator. Also, the children only went into the new area when one of the adults went there. This was possibly because most of the fence around the original play space was still in place, with only a small opening leading to the new area. During an update conversation a year and a half later, the new director reported the sawdust was no longer a problem and that the children freely went into the new space even though the dividing fence was still up.

Suzette herself was a bit disappointed in the way the nature-based play area looked once it was actually constructed. She had thought it would be larger, with the various play areas more spread out. She acknowledged that she had not had a clear sense of the measurements necessary to provide the kind of play space she envisioned. Certainly, there might be some changes that would improve this space, but overall this remains a success story. The children do have an easily accessible, safe, nature-based play space to explore every day.

\section{Change Sparked by a Single Workshop}

This article has chronicled the change in outdoor play experiences afforded to one group of young children, with the addition of a nature-based play area. The creation of this new space was the direct result of Suzette's participation in one hour of information and discussion about the importance of children being in nature. For many years, researchers and professional development facilitators have been concerned that a single professional development session rarely leads to any change in educator practice (Sparks \& Hirsh, 1997), yet that model for professional development still pervades. Joyce and Calhoun (2010) acknowledged that a single-event workshop may serve a purpose in increasing awareness of new instructional methods or curricular programs, but that such as session should be understood as a catalyst for change in teaching. The workshop may light the spark for a change, but it is usually not sufficient to fuel the fire long enough to lead to change in educators' practice. For sustained change in practice to occur after educators attend a workshop, several different forms of follow-up support such as: professional learning communities, coaching, mentoring, peer-planning and team teaching, administrative leadership, and provision of relevant resources are usually thought to be necessary (Borko, 2004; Darling Hammond, 2008; King, 2013) 
Being aware of the usual ineffectiveness of a single-event session, the author and the First Nations School Success Program coordinator intended follow-up visits to each of the province's First Nations communities in the months subsequent to the full-day workshop. But before those visits could be planned, Suzette had taken the initiative by asking for information to support her application for a grant for a nature-based playground! This wonderful, but somewhat astonishing, result from the workshop caused the author to ponder what might have led to this action. Some thoughts are offered here about why this particular director may have been inspired and able to effect this change, with connections to the concepts of horizontal and vertical transfer (Joyce \& Calhoun, 2010), the zone of proximal development (Vygotsky, 1978), and brain research, emotion and learning (Wolfe, 2006).

Why do some educators easily incorporate ideas learned at a single workshop into their practice and other educators do not change their practice at all after attending the same session? Joyce and Calhoun (2010) introduced the notions of horizontal and vertical transfer to answer this question. The term horizontal transfer refers to "an easy transition from a workshop to practice in the workplace" (p. 100) and may occur when the idea or skill described in a workshop matches the way that the educator already teaches or thinks. Vertical transfer, on the other hand, is used to describe the learning necessary when "the content of professional development is outside the normal developed repertoire of the practitioners" (p. 101). Joyce and Calhoun explained that "the more complex and more unfamiliar [ideas] require more concentration and energy if implementation is to occur" (p. 100).

Joyce and Calhoun's (2010) conceptualization of horizontal transfer and vertical transfer may be further understood by considering the concept of the zone of proximal development, defined as "the distance between the actual developmental level... and the level of potential development" (Vygotsky, 1978, p. 33). According to Vygotsky, "it is a well-known and empirically established fact... that learning should be matched in some manner with the child's developmental level" (p. 32), and he proposed that the most successful learning would occur within the zone of proximal development. The concept of the zone of proximal development has been applied to teacher education, wherein teacher educators are encouraged to draw upon the pre-service teachers' prior experiences as building blocks for current and future learning (Warford, 2011). Such an approach has long been a tenet of adult learning (Knowles, 1984).

The notions of horizontal and vertical transfer, and the zone of proximal development are further supported by current descriptions of how the human brain works. Brain imaging techniques seem to confirm that learning occurs when people can 
connect the ideas being presented to their current and past experiences. Wolfe (2006) explained that,

the brain is designed to immediately filter all incoming sensory stimuli and select only those that are relevant at that moment so as to encode them. As the brain synthesizes the data, it makes a decision to drop any information that doesn't fit easily into an existing network. (p. 36)

Recent research on the brain also confirms the role of emotion in promoting or preventing learning (Wolfe, 2006). When information has an "emotional hook" (Wolfe, 2006) the brain "initially pays attention to and retains [the] information" (p. 39).

How do these notions of horizontal transfer, the zone of proximal development, brain research, and the role of emotions in learning relate to Suzette's actions after the workshop? Suzette did mention, during a conversation soon after the workshop, that she had fond memories of playing outside as a child, so it seems there was an "emotional hook." In another conversation, Suzette explained that she was somewhat surprised and frustrated by her own children not knowing how to play outside when there was no special equipment for them, and she stated that she thought her program should include more time for play. Perhaps Suzette's current thoughts about her own children and the children she taught situated the information offered during the workshop within her zone of proximal development, so that horizontal transfer-or learning-occurred.

Another factor possibly contributing to Suzette's persistence with establishing a nature-based play space was her prior success with applying for and receiving a grant for playground equipment. That achievement surely led Suzette to be confident in her ability to replicate her success. Finally, the fact that Suzette was the director of the centre gave her the authority to make the change in the outdoor play area. Some early childhood educators have listed lack of authority as a reason for not being able to effect change (Munroe \& McLellan-Mansell, 2013).

A year after the first workshop, the author facilitated a second gathering of the educators of young children in the First Nations communities in Nova Scotia, and 75 people attended. Photos of the new nature-based play space were shown, and the educators from that centre participated in an interactive conversation about the details of changing their outdoor play space. All the participants in the room seemed to be inspired by the way the dream for change had become a reality for one of the communities, and several people left with plans to make changes at their centres. It seems this was an 
example of what Wheatley and Frieze (2007) referred to as making progress toward a goal one instance at a time by connecting "with kindred spirits." Changes may not yet have been made in all the other communities, but the children at one First Nations centre in our province do have a nature-based space to explore and enjoy, where previously they only had a commercial play structure in an area filled with crushed rock. That is cause for celebration!

\section{Acknowledgments}

The author thanks the former director of the centre referred to in this article for permission to reproduce her nature-based playground design and for her suggestions and comments on this article. She also thanks the educators and the current director for their welcome and candid conversations.

\section{Note}

1. All the research participants were guaranteed confidentiality. Therefore, the pseudonym "Suzette" will be used for this director.

\section{References}

Almon, J. (2009). The fear of play. Exchange: The Early Childhood Leaders' Magazine Since 1978, $186,42-44$.

Assembly of First Nations. (n.d.). Honoring Earth. Retrieved from http://www.afn.ca/index.php/ en/uncategorized/honoring-earth

Azlina, W., \& Zulkiflee, A. S. (2012). A pilot study: The impact of outdoor play spaces on kindergarten children. Procedia - Social and Behavioral Sciences, 38, 275-283. doi:10.1016 /j.sbspro.2012.03.349

Borko, H. (2004). Professional development and teacher learning: Mapping the terrain. Educational Researcher, 33(8), 3-15. doi: 10. 3102/0013189X033008003
Canadian Broadcasting Corporation. (Producer). (2013, May 8). David Suzuki: Get outside [Radio broadcast]. Q with Jian Ghomeshi. Retrieved from http://www.cbc.ca/q/blog /2013/05/08/david-suzuki-on-why-kids-aredisconnected-from-nature/

Copeland, K. A., Sherman, S. N., Kendeigh, C. A., Kalkwarf, H. J., \& Saelens, B. E. (2012). Societal values and policies may curtail preschool children's physical activity in child care centers. Pediatrics, 129(2), 265-274. doi:10.1542/ peds.2011-2102

Danks, S. G. (2010). Asphalt to ecosystems: Design ideas for schoolyard transformation. New Village Press: Oakland, CA. 
Darling-Hammond, L. (2008). B. Teacher learning that supports student learning. In B. Z. Presseisen (Ed.), Teaching for Intelligence, 2nd Ed. (pp. 91-100). Thousand Oaks, CA.: Corwin.

David Suzuki Foundation. (Producer). (n.d.). $30 \times 30$ Nature Challenge. Retrieved from http://30x30.davidsuzuki.org/2013/04/adda-daily-dose-of-nature-join-the-30×30-na ture-challenge/

Dwyer, G. M., Higgs, J., Hardy, L. L., \& Baur, L. A. (2008). What do parents and preschool staff tell us about young children's physical activity: A qualitative study. International Journal of Behavioral Nutrition and Physical Activity, 5(66). doi:10.1186/1479-5868-5-66

Fjørtoft, I. (2004). Landscape as playscape: The effects of natural environments children's play and motor development. Children, Youth and Environments, 14(2), 21-44. Retrieved from http://www.stichtingoase. $\mathrm{nl} /$ literatuur/doc/doc_76.pdf

Fjørtoft, I., \& Sageie, J. (2000). The natural environment as a playground for children: Landscape description and analysis of a natural landscape. Landscape and Urban Planning, 48(1/2) 83-97. doi:10.1016/ S0169-2046(00)00045-1

Gill, T. (2005, October 3). How to let your children run free. The Independent. Retrieved from http://www.independent.co.uk/environment/how-to-let-your-children-runfree-509400.html

Greenwood, M. (2009). Places for the good care of children: A discussion of Indigenous cultural considerations and early childhood in Canada and New Zealand (Doctoral dissertation). University of British Columbia, Vancouver, Canada. Retrieved from https://circle.ubc.ca/ bitstream/handle/2429/14838/ubc_2009_ fall_greenwood_margo.pdf?sequence $=1$

Greenwood, M., \& Shawana, P. (2003). Whispered gently through time: First Nations quality child care. Native Social Work Journal, 4(1), 51-83. Retrieved from http://zone.biblio.laurentian.ca/dspace/bitstream/10219/433/1/ NSWJ-V4-art3-p51-83.pdf

Guskey, T. (2002). Professional development and teacher change. Teachers and Teaching: Theory and Practice, 8(3), 381-391.
Handler, D., \& Epstein, A. S. (2010). Nature education in preschool. Highscope Extensions, 25(2), 1-7. Retrieved from http://www. highscope.org/file/Newsandlnformation/ Extensions/Ext_Vol25No2_low.pdf

Harvest Resources. (2006). Leave no child inside: Outdoor ECE programs: A study guide for early childhood educators [CD]. Mechanicsburg, PA: Author.

Joyce, B., \& Calhoun, E. (2010). Models of professional development: A celebration of educators. Thousand Oaks, CA: Corwin.

Keeler, R. (2008). Natural playscapes: Creating outdoor play environments for the soul. Redmond, WA: Exchange Press.

Kernan, M. (2010). Being confined within? Constructions of the good childhood and outdoor play in early childhood education and care settings in Ireland. Children and Society, 24(5), 371-385. doi:10.1111/j.1099-0860.2009.00249.x

King, F. (2013). Evaluating the impact of teacher professional development: An evidencebased framework. Professional Development in Education. Retrieved from http://dx.doi. org/10.1080/19415257.2013.823099

Knowles, M. S. (1984). Andragogy in action: Applying modern principles of adult learning. San Francisco: Jossey-Bass.

Little, H., \& Eager, D. (2010). Risk, challenge and safety: Implications for play quality and playground design. European Early Childhood Education Research Journal, 18(4), 497-513. doi:10.1080/1350293X.2010.525949

Louv, R. (2005). Last child in the woods: Saving our children from nature-deficit disorder. Chapel Hill, NC: Algonquin Books

Louv, R. (2011). The nature principle: Reconnecting with life in a virtual age. Chapel Hill, NC: Algonquin Books.

Mauffette, A. G. (1998). Revisiting your outdoor environment: Reasons to reshape, enrich, redevelop the outdoor space. Canadian Children, 23(2), 17-21. 
Miller, D. L. (2007). The seeds of learning: Young children develop important skills through their gardening experiences at a Midwestern early education program. Applied Environmental Education and Communication, 6(1), 49-66. doi:10.1080/ 15330150701318828

Munroe, E., \& McLellan-Mansell, A. (2013). Outdoor Play Experiences for Young First Nations Children in Nova Scotia: Examining the Barriers and Considering Some Solutions. Canadian Children, 38(2), 25-33.

Organisation mondiale pour l'éducation prescolaire/World Organization for Early Childhood Education (OMEP). (Producer). (2010). Child participation outdoors in the Swedish preschool [DVD]. (Distributed at the 2010 OMEP conference in Gothenburg, Sweden.)

Sparks, D., \& Hirsh, S. (1997). A new vision for staff development. Alexandria, VA: Association for Supervision and Curriculum Development and National Staff Development Council.

Stairs, A. H., \& Bernhard, J. K. (2002). Considerations for evaluating 'good care' in Canadian aboriginal early childhood settings. McGill Journal of Education, 37(3), 309331. Retrieved from http://digitalcommons. ryerson.ca/ ece/7

Stephenson, A. (2003). Physical risk-taking: Dangerous or endangered? Early Years, 23(1), 35-43. doi: 10.1080/0957514032000045573

Tandon, P. S., Zhou, C., Lozano, P., \& Christakis, D. (2011). Preschooler's total daily screen time at home and by type of childcare. Journal of Pediatrics, 158(2), 297-300.
Vadala, C. E., Bixler, R. D., \& James, J. J. (2007). Childhood play and environmental interests: Panacea or snake oil? Journal of Environmental Education, 39(1), 3-17. Retrieved from http://search.proquest. com.libproxy.stfx.ca/docview/233051157/ fulltextPDF?accountid=13803

Vygotsky, L. (1978). Interaction between learning and development. In Mind and Society (pp. 79-91). Cambridge, MA: Harvard University Press.

Warford, M. (2011). The zone of proximal teacher development. Teaching and Teacher Education, 27, 252-258. doi:10.1016/j.tate. 2010.08.008

Wheatley M., \& Freize, D. (2007, Winter). Using emergence to take social innovations to scale. Shambala Institute for Authentic Leadership Fieldnotes, pp. 1-5. Retrieved from https:// www.ohrd.wisc.edu/Home/Portals/0/ Week5WheatleyandFriezeEmergence.pdf

White, R. (n.d.). Benefits for children of play in nature. Retrieved from http://www.white hutchinson.com/children/articles/benefits. shtml

White, R. (2004). Young children's relationship with nature: Its importance to children's development \& the earth's future. Retrieved from http://www.childrenandnature.org/ research/volumes/C16/16

Wolfe, P. (2006, Spring). The role of meaning and emotion in learning. New Directions for Adult and Continuing Education, 110, 35-41. doi:10.1002/ace.217

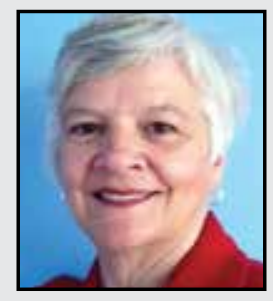

Elizabeth Munroe is an Assistant Professor in the Faculty of Education at St. Francis Xavier University in Antigonish, Nova Scotia. Elizabeth's research interests focus upon the process of professional learning. Elizabeth has recently completed a three-year collaborative research project with the Mi'kmaw Kina'matnewey First Nations Student Success Program in Nova Scotia, specifically working with the educators of children who are not yet in formal school settings. 